\author{
Самофратова B.A. \\ кандидат економічних наук, доцент \\ E-mail: vica_samofatova@mail.ru \\ Паньків Ю.П. \\ Магістрант \\ кафедра економіки промисловості \\ Одеська національна академія харчових технологій \\ вул. Канатна, 112, м. Одеса, Україна, 65039 \\ E-mail:220i@i.ua
}

\title{
ОСНОВНІ ТЕНДЕНЦІЇ ВИРОБНИЦТВА І СПОЖИВАННЯ РИБИ ТА РИБНОÏ ПРОДУКЦІї В УКРАЇНІ
}

У статті розглянуто основні тенденції виробництва і споживання риби та рибної продукції в Україні. Під час проведення аналізу були визначені основні проблемні моменти функціонування рибопереробних підприємств України. Виявлено перспективи подальшого розвитку підприємств галузі та запропоновані заходи для досягнення необхідного результату.

Ключові слова: риба, рибна продукція, виробництво риби, споживання риби, вилов риби.

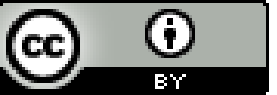

This work is licensed under a Creative Commons Attribution 4.0 International License http://creativecommons.org/licenses/by/4.0/
Постановка проблеми та її зв'язок з важливими науковими та практичними завданнями. Виробництво і споживання риби та рибної продукції в Україні протягом останніх років відчутно знизилося. Насамперед це сталося через зменшення вилову в Україні та значного подорожчання імпортної продукції через знецінення національної валюти. Тому потрібно проаналізувати виробництво і споживання риби та рибної продукції в Україні для визначення основних тенденцій розвитку галузі в цілому.

Аналіз останніх публікацій по проблемі. Дослідженню ефективних напрямків розвитку рибопереробної галузі України присвячені роботи таких вчених, як Багрова О.М., Загороднюк О.В.,[1,2], Степанова В.М., Борщевського П.П., Стасишена М.С. [5], Гринжевського М.В. [7], Вдовенко Н.М. [3], Алимова С.І., Козій С.О. [8] та інших дослідників. Якщо детальніше, то в їх наукових роботах багатоаспектно досліджувався стан виробництва продукції та перспективи розвитку підприємств рибного господарства. Однак, зважаючи на різкі зміни в політичному та економічному житті країни, слід активізувати визначені тенденції, що і зумовило написання даної статті.

Формулювання цілей дослідження. Метою статті є дослідження основних тенденцій виробництва та споживання риби та рибної продукції.

Виклад основних результатів і їх обгрунтування. Україна володіє найбільшою площею внутрішніх водойм в Свропі - близько 1,3 млн. га. При цьому $80 \%$ рибної продукції, які споживають українці - це імпорт. 3 цією проблемою потрібно боротися, навіщо імпортувати рибу та рибну продукції з інших країн, якщо ії можна вирощувати і в нашій країні. Отже, для початку, проаналізуємо детальніше виробництво риби в Україні.

За результатами 2015 року загальний обсяг вилову риби та добування інших водних біоресурсів в Україна склав всього лише 88,6 тис. тонн, що менше на 2,7 тис. тонн проти 2014 року, а якщо брати в порівнянні з 2013 роком, то вилов риби зменшився на 137,2 тис. тонн. Насамперед це сталося через анексію Криму [3].

Крим:

Втрати рибопереробної галузі від анексії АР

- загальний обсяг вилову живих біоресурсів в Україні зменшився на 63\%. У 2014 р. економічні втрати від скорочення промислу було оцінено в 363 млн грн.;

- загальні втрати державного майна галузі через анексію Криму та бойові дії в зоні АТО оцінюються в 349,2 млн грн.;

- щорічний недоотриманий чистий прибуток державних підприємств становить 20 млн грн., державний бюджет недоотримує податків майже на 37 млн грн.;

- втрачено контроль над двома морськими рибними портами - Севастопольським і Керченським. Також втрачені 10 переробних заводів, що виробляли 70\% консервів в Україні. [10]

Крім того, негативно вплинули на рибопереробні галузь України багато політичних i економічних факторів, серед таких можна виділити тимчасову окупацію окремих територій Донецької та Луганської областей та девальвація гривні.

Представимо динаміку обсягу вилову риби та добування інших водних біоресурсів за 10 років, 3 2006 р. по 2015 р. (рис. 1.) 


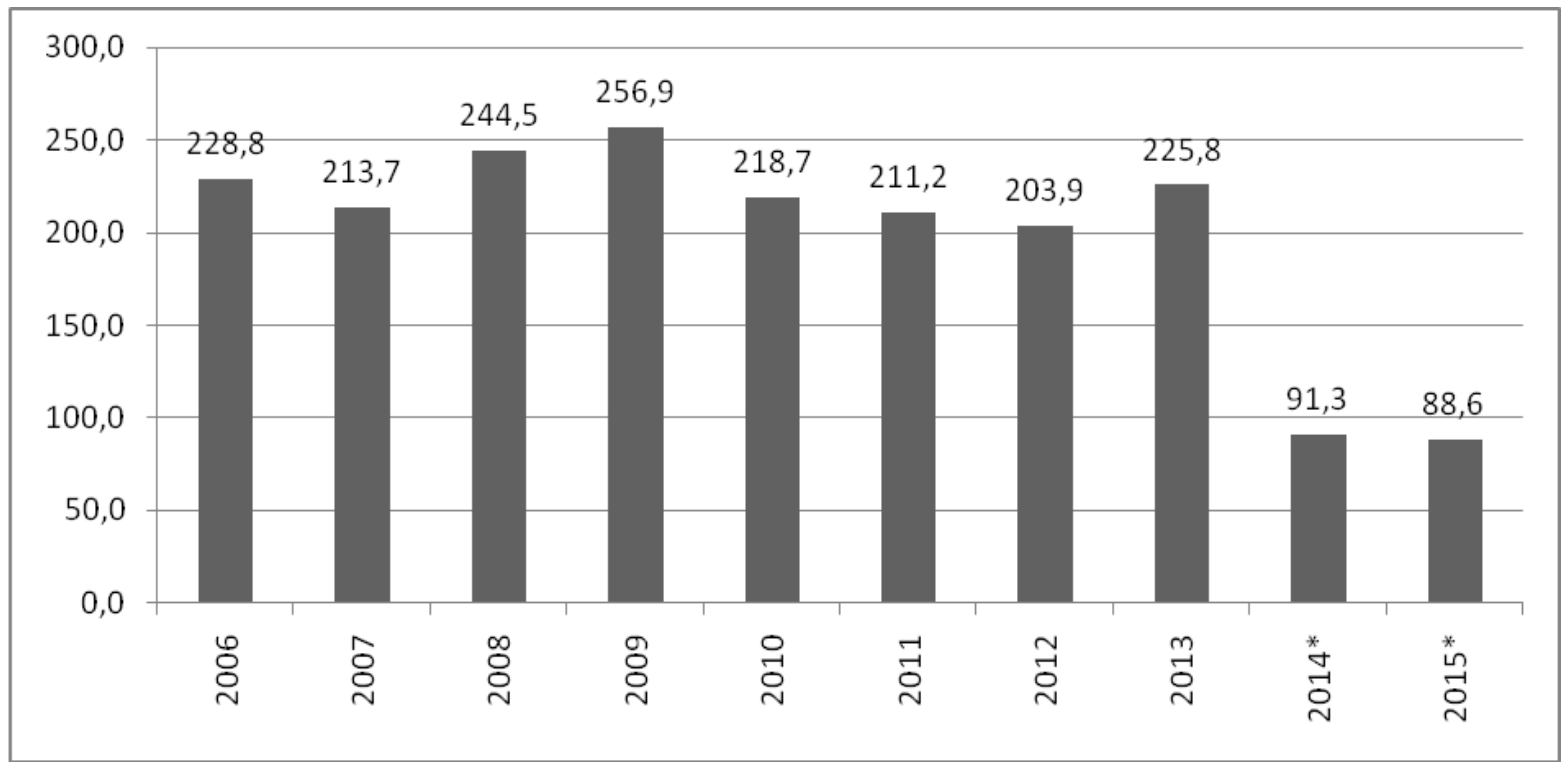

2014, 2015* - Без урахування тимчасово окупованої території Автономної Республіки Крим і м. Севастополя

Рис. 1. Динаміка обсягу вилову риби та добування інших водних біоресурсів в країні та на території морських економічних зон України, тис. тонн [9]

Зазначена динаміка свідчить, що обсяг вилову риби та добування інших водних біоресурсів за останні роки критично зменшився, орієнтовно у 3 рази.

Проаналізуємо споживання риби рибної продукції в Україні.

За останні десятиліття споживання риби зазнало величезних змін. Так, світове видиме споживання риби на душу населення неухильно збільшувалося: з 10 кг в середньому в 1960-ті роки до 11,5 кг в 1970-ті роки, 12,5 кг — в 1980-ті роки, 14,4 кг — в 1990-ті роки і досягло 16,4 кг в 2005 році. В Україні ж споживання в 1990 році складало 17,5 кг. У подальшому до 1995 року український ринок споживання риби на одну особу катастрофічно знизився до найнижчого рівня - менше 4 кг за рік. I з того часу почалося помітне стабільне зростання: до 8 кг/рік у 2000 та до 12 - у 2002 році. [4] Надалі, у 2005 р. споживання рибних продуктів досягло 14,4 кг/рік і трохи наблизилося до загальносвітового показника -
16 кг/рік, а в 2008 р. перевищило 17 кг/рік (табл.1) . Разом 3 тим, зростання споживання риби у абсолютному вимірі супроводжувалося й зростанням ії частки в загальному кошику українського споживача .

В 2014 році ситуація істотно змінилася, споживання риби зменшилось до 10,8 кг. на одну людину на рік. Головною причиною зменшиться вважається підвищення ціни за 1кг. В 2015 році показник впав до 7,8 кг., що набагато нижче обгрунтованої норми, яка становить 19-20 кг. на одну людину. Для порівняння: у країнах Східної Свропи, близьких до України за культурними традиціями та споживчими перевагами, цей показник становить 14кг/люд. (в Іспанії - 38, у Норвегії - 50, в Ісландії - 90 кг/люд. за рік) [6].

Враховуючи те, що ціна на рибу та рибну продукцію не падає можна спрогнозувати зменшення споживання в 2016 році, але щоб цього не сталося потрібно діяти, плани втілювати в реальність.

Таблиця 1

Споживання риби і рибопродуктів в Україні, кг на одну особу за рік [9]

\begin{tabular}{|l|c|c|c|c|c|c|c|c|c|c|}
\hline \multirow{2}{*}{\multicolumn{1}{|c|}{ Показник }} & \multicolumn{10}{c|}{ Pік } \\
\cline { 2 - 13 } & 2006 & 2007 & 2008 & 2009 & 2010 & 2011 & 2012 & 2013 & 2014 & 2015 \\
\hline $\begin{array}{l}\text { Риба і рибопродук- } \\
\text { ти }\end{array}$ & 14,1 & 15,3 & 17,5 & 15,1 & 14,5 & 13,4 & 13,6 & 14,6 & 10,8 & 7,8 \\
\hline
\end{tabular}

В результаті дослідження, нами були виділенні основні проблеми рибопереробної галузі України. Зокрема, однією 3 основних проблем являється застаріле обладнанням на більшості рибопереробних підприємств. В зв'язку з цим, підприємства не мають можливості нарощувати обсяги виробництва та зменшити собівартість виробленої продукції, навпаки 3 кожним роком обладнання зношується, відповідно продуктивність обладнання знижується, а собівартість продукції збільшується. Отже рибопереробним підприємствам потрібно оновлювати матеріально-технічну базу. Враховуючи зменшення 
державного фінансування підприємств рибопереробної галузі придбати нове обладнання, на даний час, без залучення інвестицій не можливо.

Застаріле обладнання та відсутність установок для переробки відходів підприємств рибопереробної галузі приводить нас до другої проблеми - забруднення навколишнього середовища.

За ступенем інтенсивності негативного впливу підприємств рибної промисловості на об'єкти довкілля перше місце посідають водні ресурси.

По витраті води на одиницю випущеної продукції рибна промисловість займає одне 3 перших місць серед галузей народного господарства. Високий рівень споживання обумовлює великий обсяг стічних вод на підприємствах, при цьому вони мають високий ступінь забрудненості і становлять небезпеку для навколишнього середовища.

Скидання стічних вод у водойми швидко виснажує запаси кисню, що викликає загибель мешканців цих водойм. Для стічних вод характерний високий показник вмісту зважених органічних речовин. Цей осад протягом багатьох років накопичується у відстійниках і на полях фільтрації, що призводить до переповнення карт полів фільтрації і потрапляння стічних вод у відкриті водойми.

Стічні води рибопереробного підприємства утворюються в основному при митті риби, миття обладнання, інвентарю, тари та підлог. У виробничий стік потрапляють жир, кров, білки, сіль, фосфати. Стічні води підприємств рибної промисловості мають високий ступінь бактеріального обсіменіння. Тому перед скиданням у водойми або на земляні майданчики стічних вод підприємств рибної промисловості ïх необхідно піддавати механічної та біологічної очистці та знезараженню.

Щоб зменшити екологічні проблеми, пов'язані 3 утворенням рибних відходів, необхідне впровадження нових виробничих потужностей, з безвідходної переробки водних біологічних ресурсів.

Також необхідно проаналізувати фактичну обстановку рибних відходів та їх подальшої утилізації. Для цього слід рекомендувати муніципальним органам влади провести роботу 3 підприємствами, вказати на не припустимо утилізації рибних відходів 3 порушенням вимог чинного законодавства. Крім того, необхідно посилити контроль над підприємствами, що займаються переробкою риби і морепродуктів щодо дотримання ними природоохоронного законодавства.

Переробка відходів здійснюється в незначних кількостях, потенціал відходів, як сировини для виробництва товарної продукції, не використовується. Тому нами пропонується організувати їх переробку i створити підприємство спільної переробки відходів рибної та сільськогосподарських галузей методом екстрагування, 3 отриманням кормових добавок в якості товарної продукції.
Ще однією з проблем функціонування рибопереробних підприємств являється незабезпеченість власною сировиною. За даними статистики України більше 70 \% імпортованої риби йде на переробку, в основному це заморожена риба.

Основу імпортної мороженої риби становить традиційний продукт для населення України - оселедець, скумбрія, сардина та кілька або шпрот. Також в нашу країну імпортується готова або консервована риба, продукти із сурмі (крабові палички), що становить майже 4,6\% всього імпорту.

Зараз те, що імпортна риба дуже подорожчала, це великий шанс для української продукції - замінити на прилавках дорогу імпортну продукцію. Це відкриє покупцеві доступ до якісної вітчизняної продукції за нижчою ціною.

Проаналізувавши виробництва і споживання риби та визначивши проблеми рибопереробної галузі нами були виділені наступні завдання та тенденції для іiі розвитку, які потрібні втілювати вже сьогодні, щоб отримати позитивний результат:

1. За прикладом європейських країн потрібно запровадити сертифікати походження рибної продукції. Зараз неможливо встановити, що за риба на прилавках - легально чи нелегально виловлена, рибу супроводжує сертифікат відповідності, але він стосується тільки якості продукту.

2. Потрібно створити рибний патруль у всіх областях України, який буде перевіряти легальність вилову риби.

3. Підвищити відповідальності за браконьєрський вилов риби, тим самим збільшити легальний вилов риби.

4. Потрібно будувати більше штучних сполучень між лиманом та морем для збільшення вітчизняного виробництва риби, що в свою чергу дасть змогу постачати рибу та рибну продукцію на рибопереробні підприємства в повному обсязі, забезпечуючи їх вітчизняною сировиною.

5. Рибопереробним підприємствам потрібно збільшити долю вітчизняної продукції у своїй діяльності, цим вони здешевлять свою продукцію і збільшать попит.

6.Потрібно модернізувати рибопереробні підприємства, оновити матеріально-технічну базу за рахунок залучення інвестицій.

Висновки та перспективи подальших досліджень. Виділені нами основні тенденції, завдання виробництва і споживання риби та рибної продукції України є дуже важливими, це мінімальна програма для подальшого розвитку галузі. Виконання даних завдань дасть змогу збільшити вилов риби та зменшити іi імпорт, в свою чергу вітчизняна продукція значно дешевше чим зарубіжна, що вплине i на збільшення обсягу споживання. 


\section{Література}

1. Загороднюк О. В. Формування та розвиток ринку риби і рибної продукції України : автореф. дис. канд. ек. наук : спец. 08.00.03 - «Економіка і управління національним господарством» / О. В.Загороднюк. Одеса. $-2012 .-24$ c.

2.Загороднюк О. В. Перспективи розвитку вітчизняного ринку риби / О. В. Загороднюк // Вісник Полтавської державної аграрної академії. - 2011. - №1. -С. 18 - 25.

3. Вдовенко Н.М. Сучасний стан та напрями розвитку рибного господарства в Україні / Н.М. Вдовенко // Економіка агропромислового виробництва. - 2010. - № 3. - С. 15-20.

4. Сучасний стан рибної галузі України та вітчизняного ринку рибної продукції / [Смирнюк Н.І., Буряк I.В., Загороднюк А.О., Марценюк Н.О.] // Рибне господарство. -2005. - Вип. 64. - С. 143-153.

5.Стасишен М.С. Економічні проблеми розвитку рибного господарства України / М.С. Стасишен; ред. П.П. Борщевський. - К., 1998. -292 с.

6.Алимов С. І. Рибне господарство України: стан і перспективи / С. І. Алимов. - К.: Вища освіта, 2003. $-335 \mathrm{c}$.

7. Гринжевський М. В. Фактори підвищення ефективності рибного господарства / М. В. Гринжевський // Вісник аграрної науки. -1999. - № 4. - С. 34-40.

8. Козій С.О. Перспективи розвитку ринку риби і рибної продукції / С.О. Козій // Экономические инновации. - 2004. - Вып. 19.- С. 230-236.

9.Офіційний сайт Державного комітету статистики України. http://ukrstat.gov.ua.

10.Офіційний сайт Державного агенства рибного господарства України. http://darg.gov.ua.

Стаття надійшла 12.05.2016

Стаття прийнята до друку 26.05.2016

\section{Самофратова B.A.}

кандидат экономических наук, доцент

E-mail: vica_samofatova@mail.ru

Панькив Ю.П.

магистрант

кафедра экономики промышленности

Одесская национальная академия пищевых технологий

ул. Канатная, 112, м. Одеса, Украина, 65039

E-mail:220i@i.ua

\section{ОСНОВНЫЕ ТЕНДЕНЦИИ ПРОИЗВОДСТВА И ПОТРЕБЛЕНИЯ РЫБЫ И РЫБНОЙ ПРОДУКЦИИ В УКРАИНЕ}

В статье рассмотрены основные тенденции производства и потребления рыбы и рыбной продукции в Украине.

На сегодняшний день наблюдается упадок рыбоперерабатывающей отрасли Украины - ежегодно уменьшается вылов рыбы во внутренних водоемах Украины, уменьшается количество потребления рыбы и рыбной продукции на душу населения, прежде всего на это влияют политические и экономические фракторы страны. Среди них можно выделить аннексию АР Крым, временную оккупацию отдельных территорий Донецкой и Луганской областей и девальвацию гривны. Начиная с 2014 года курс гривны начал стремительно снижаться, иногда достигая уровня в 40 гривен за 1 американский доллар.

Проведенный анализ позволил определить основные проблемные моменты функционирования рыбоперерабатывающих предприятий Украины. Одной из основных проблем является наличие устаревшего оборудования, которое с каждым годом изнашивается, соответственно его производительность падает, что в значительной степени влияет на себестоимость продукции; второй проблемой является загрязнение окружающей среды путем попадания сточных вод предприятия, которые образуются в основном при мытье рыбы, мойке оборудования, инвентаря, тары и полов в открытые водоемы. В производственный сток попадают жир, кровь, белки, соль, фосфаты. Еще одной из проблем фрункционирования рыбоперерабатывающих предприятий является необеспеченность собственным сырьем, что заставляет их закупать не дешевую импортную рыбу.

Выявлены перспективы дальнейшего развития предприятий отрасли и предложены следующие меры для достижения необходимого результата: внедрение сертификатов происхождения рыбной продукции; создание рыбного патруля во всех областях Украины; повышение ответственности за браконьерский вылов рыбы; увеличение строительства искусственных соединений между лиманом и 
морем; увеличение доли переработки отечественной рыбной продукции рыбоперерабатывающими предприятиями; модернизация рыбоперерабатывающих предприятий, обновление материальнотехнической базы. Внедрение вышеперечисленных мероприятий приведет к улучшению состояния рыбоперерабатывающей отрасли Украины и получению дополнительных средств в бюджет страны.

Ключевые слова: рыба, рыбная продукция, производство рыбы, потребление рыбы, вылов рыбы.

\author{
Samofatova V. \\ Ph.D., Associate Professor \\ E-mail: vica samofatova@mail.ru \\ Pankiv Y. \\ Undergraduate \\ Department of Industrial Economics \\ Odessa National Academy of Food Technologies \\ Kanatna str., 112, Odessa city, Ukraine, 65039 \\ E-mail:220i@i.ua
}

\title{
MAIN TRENDS OF PRODUCTION AND CONSUMPTION OF FISH AND FISH PRODUCTS IN UKRAINE
}

The article examines the main trends of production and consumption of fish and fish products in Ukraine. To date, there is decline in the fish processing industry in Ukraine - annually reduced fishing in inland waters of Ukraine, reducing the amount of consumption of fish and fish products per capita, first of all it affects the political and economic factors of the country. Among them are the annexation of Crimea, the temporary occupation of certain areas of the Donetsk and Lugansk regions and the devaluation of the hryvnia. Beginning in 2014, the hryvnia began to fall rapidly, sometimes reaching a level of 40 hryvnia for one dollar.

The analysis allowed to identify the main problematic aspects of functioning fish processing enterprises of Ukraine. One of the main problems is the presence of obsolete equipment that wears out each year, according to its productivity falls, which greatly affects the cost of production; the second problem is the pollution of the environment by entering the waste water companies, which are formed mainly when washing the fish, cleaning equipment, inventory, packaging and flooring in the open water. The production flow fall fat, blood, proteins, salt, phosphates. Another one of the problems of functioning fish processing enterprises is the insecurity of its own raw materials, which makes them not to buy cheap imported fish.

Revealed the prospects of further development of the industry, and the following measures are proposed in order to achieve the desired result: the introduction of certificates of origin of fish products; Fisheries patrol creation in all regions of Ukraine; increasing responsibility for poaching fish; an increase in the construction of artificial connections between the estuary and the sea; increasing the share of domestic processing of fishery products of fish processing plants; modernization of fish processing plants, upgrading the material and technical base. Implementation of the above measures will lead to an improvement in the fish processing industry in Ukraine and the state of obtaining additional funds to the state budget.

Keywords: fish, fish products, fish production, fish consumption, fishing.

\section{References}

1. Zahorodniuk, O. V. (2012). Formuvannia ta rozvytok rynku ryby i rybnoi produktsii Ukrainy. Odesa.

2. Zahorodniuk, O. V. (2011). Perspektyvy rozvytku vitchyznianoho rynku ryby. Visnyk Poltavskoi Derzhavnoi Ahrarnoi Akademii, 1, 18-25.

3. Vdovenko, N. M. (2010). Suchasnyi stan ta napriamy rozvytku rybnoho hospodarstva v Ukraini. Ekonomika Ahropro $\neg$ myslovoho Vyrobnytstva., 3, 15-20

4. Smyrniuk, N. I., Buriak, I. V., Zahorodniuk, A. O., \& Martseniuk, N. O. (2005). Suchasnyi stan rybnoi haluzi Ukrainy ta vitchyznianoho rynku rybnoi produktsii. Rybne Hospodarstvo, 64, 143-153. Ukrainy. K.

5 Stasyshen, M. S., \& Borshchevskyi, P. P. (1998). Ekonomichni problemy rozvytku rybnoho hospodarstva

6. Alymov, S. I. (2003). Rybne hospodarstvo Ukrainy: Stan i perspektyvy. K.: Vyshcha osvita. Nauky, 4, 34-40.

7. Hrynzhevskyi, M. V. (1999). Faktory pidvyshchennia efektyvnosti rybnoho hospodarstva. Visnyk Ahrarnoi $19,230-236$.

8. Kozii, S. O. (2004). Perspektyvy rozvytku rynku ryby i rybnoi produktsii. Эkonomycheskye Ynnovatsyy,

9. Ofitsiinyi sait Derzhavnoho komitetu statystyky Ukrainy. Retrieved from http://ukrstat.gov.ua

10. Ofitsiinyi sait Derzhavnoho ahenstva rybnoho hospodarstva Ukrainy. Retrieved from http://darg.gov.ua

Received 12 May 2016

Approved 26 May 2016

Available in Internet 29.06.2016 